\title{
Motor skill development for children between the ages of 6 to 8 as a result of finishing an initiation level swimming course
}

\author{
Dan Ionuț PÎRJOL ${ }^{1}$, Marcel RĂSĂDEAN², Petre BANIAȘ 3
}

\begin{abstract}
Introduction: Swimming, as an activity, covers many of the basic humanistic needs by creating a state of wellbeing as well as help form a holistic person by developing their motor skills, cognition and affection through the stresses of training for competition or just by practicing for recreational purposes. Various scientific studies show the importance of the motor skill component when selecting those fit for competitive swimming. Additionally, there are other studies that demonstrate that swimming can have an anthropometric effect over the body. The purpose of our study was to test if an initiation level swimming course would produce a development of basic motor skills in children between the ages of 6 to 8 . Methodology and Participants: for this study we recruited 10 participants out of which 5 were girls and the remaining 5 were boys. Their age $(7,1 \pm 0,73)$ is between 6 and 8 where two of the children are 6 years of age, five are 7 years of age and the last three are 8 years of age. In order to conduct the study, we employed a set of tests that rely on 7 events extracted from the stock of EUROFIT tests. Results: the final results show that the participants have improved their performances with strong statistical significance. Conclusions: Undergoing an initiation level swimming course results in a noticeable development of motor skills as well as from the homogeneity of the group, which is considerably improved at final testing.
\end{abstract}

Key words: swimming, motor skill, initiation.

\section{Rezumat}

Introducere: Înotul acoperă necesităţile de bază ale ființei umane de la o stare de bine, la o formare integrală a persoanei din punct de vedere motor, cognitiv, afectiv, de la îmbunătăţirea condiţiei fizice la necesitatea antrenării pentru competiţii sau doar în sens recreativ. Există studii de specialitate care demonstrează importanța calitătilor motrice în selecția pentru înotul de performanță. Alte cercetări ne arată importanța practicării cursurilor de înot asupra schimbărilor indicilor antropometrici. Scopul studiului nostru a fost de a verifica dacă prin parcurgerea lecților de inițiere în înot a copiilor de 6-8 ani, dezvoltăm calitățile motrice de baza. Participanți și metoda: pentru acest studiu am recrutat 10 subiecţi, dintre care 5 fete si 5 băieți, în ceea ce priveşte vârsta subiecților $(7,1 \pm 0,73)$, ea este cuprinsă între 6 şi 8 ani, dintre care 2 copii au vârsta de 6 ani, 5 au vârsta de 7 ani și 3 subiecţi au 8 ani. În vederea realizării cercetării a fost realizat un set de teste care conţine 7 probe, din bateria de teste EUROFIT. Rezultate: din testările finale reiese faptul că atat performanţele testaţilor au fost îmbunătăţite, cât şi omogenitatea a fost mai mare din punct de vedere statistic, iar diferențele au fost semnificative. Concluzii: Practicarea cursurilor de iniţiere înot, au un impact important asupra organismului atât din punct de vedere al calităţilor motrice care se dezvoltă simţitor, cât şi din punct de vedere al omogenităţii grupului care se imbunătățeşte considerabil la testarea finală.

Cuvinte cheie: înot, calități motrice, inițiere.

\footnotetext{
${ }^{1}$ PhD Student, West University of Timisoara, Romania, Faculty of Physical Education and Sport, e-mail: ionut.pirjol07@gmail.com

${ }^{2}$ Lecturer, West University of Timisoara, Romania, Faculty of Physical Education and Sport

${ }^{3}$ Assoc. Prof., West University of Timisoara, Romania, Faculty of Physical Education and Sport
} 


\section{Introduction}

Swimming meets the basic needs of a human being, from general well-being to wholesome personal development in regards to motor, cognitive and emotional function. Its benefits are reaped whether it is engaged in for general fitness, as competition training, or just for fun.

The greatest advantage swimming presents is that the muscles and joints are exercised without having to support body weight, therefore reducing tension and minimizing the risk of injury. A good candidate for such exercise would be someone whose daily work proves a major strain on their joints, especially the knees and hips. During exercise in water, such strain is not felt, since the effects of gravity are felt differently $[3,11]$.

All sports have health benefits when correctly engaged in. Swimming, however, has a set of unique characteristics that other types of aerobic exercise do not have. Among them, it leads to remarkable cardiac-pulmonary endurance, it stimulates blood flow, contributes to stable blood pressure, reduces the risk of heart disease, it develops most muscle groups, strengthens ligaments, enhances flexibility, helps ameliorate anxiety and depression, stimulates physical and psychological growth and improves psycho-motor functions [1, 3].

Motor capacity is an organism's attribute that governs its ability to move with a certain speed, force, endurance and skill [7].

The aim of this paper is to prove that children's base motor functions (speed, endurance, force, skill and mobility) are developed when they engage in basic swimming lessons, and that group homogeneity increases.

Specialist studies prove the significance that motor function has in the selection process for performance swimming.[5] Other studies show the importance of swimming in relation to changing anthropometric parameters [9].

A recent study (2015) details the significant changes in motor function that a group of first graders in a Polish school underwent, after going through a swimming course [6].

\section{Materials and methods}

Research was conducted in Timişoara, during the months of April and July 2014, tests being run on the children who regularly attend the swimming courses held by the Studio Fit sports club in Dumbrăviţa.

Ten subjects underwent tests, of which five boys and five girls, all aged between 6 and 8 years old (median age $7.1 \pm 0.73$ ). Two children were of age 6 , five of age 7 and three of age 8 .

Testing for this piece of research consisted of a set of 7 tasks selected from the EUROFIT set [8].

The experiment consisted in testing children before starting out the swimming course and after 2 months of training in the water. Sessions were organized 2 times a week, every Tuesday and Thursday, each lesson taking 55 minutes. The lessons included all the specific steps of learning how to swim. $[1,10]$ The training spanned a total of 16 hours of swimming, children gladly engaging in all sessions.

The 7 tasks engaged in as part of testing were:

1. A $5 \times 5 \mathrm{~m}$ shuttle run test which involves sprinting at maximum speed and changing direction

2. Push-ups to measure upper body strength and speed

3. Squats to measure lower body strength and speed

4. Standing broad jump test, measuring explosive leg power

5. Abdominal crunches to measure core muscle strength and speed

6. Back extensions, measuring back muscle strengthens

7. Sit and reach test to measure spinal cord flexibility.

\section{Results}

For this paper we have used the GraphPad Prism 6 statistics analysis software in conjunction with the paired $\mathrm{T}$ test to analyze result variations, both in the initial and final tests. 
Tabel 1. Results

\begin{tabular}{|l|c|c|c|c|}
\hline Task & \multicolumn{2}{|c|}{ Average } & \multicolumn{2}{c|}{ Variation coefficient } \\
\hline & $\begin{array}{c}\text { Initial } \\
\text { test }\end{array}$ & Final test & Initial test & Final test \\
\hline P1 & 8.7 & 7.5 & $22 \%$ & $18 \%$ \\
\hline P2 & 24.5 & 27 & $14 \%$ & $12 \%$ \\
\hline P3 & 28.3 & 31.5 & $21 \%$ & $14 \%$ \\
\hline P4 & 108.6 & 119.8 & $24 \%$ & $18 \%$ \\
\hline P5 & 19.1 & 22.7 & $42 \%$ & $30 \%$ \\
\hline P6 & 20.7 & 22.6 & $20 \%$ & $18 \%$ \\
\hline P7 & 2.7 & 3.2 & $50 \%$ & $47 \%$ \\
\hline
\end{tabular}

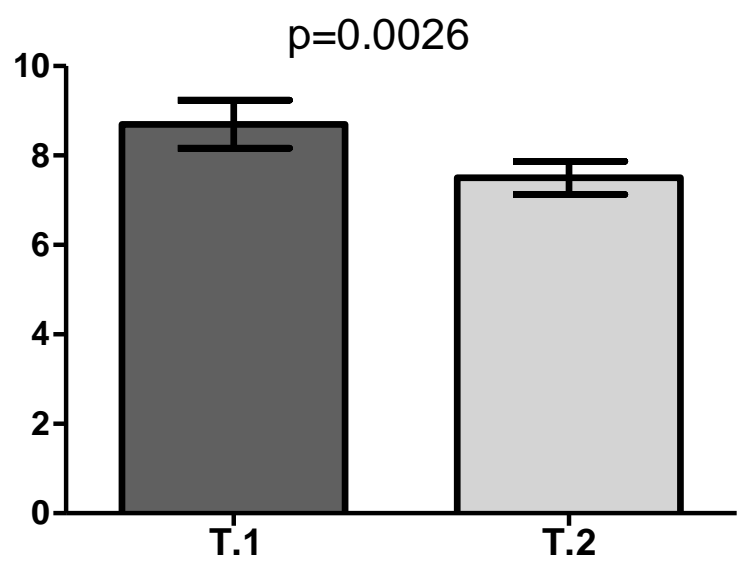

Figure 2. Trend for Task no. 1 - Shuttle Run Test Legend: T.1: Initial testing; T.2: Final testing.

Result analysis shows that most subjects have improved their performance by 1 to 3 seconds. Subject no. 2 improved the most, gaining 3 seconds. The other results were comprised of: 2 subjects progressed by 2 seconds, 5 subjects progressed by 1 second and 2 did not register any progress.

Result variability has also dropped, from an initial value of $22 \%$ to a final value of $18 \%$. Statistically, the group has medium variability, since the final calculated value (18\%) fits into the $10-20 \%$ range. After calculating the P value $(0.0026)$, the difference between the initial and final tests is not statistically significant.

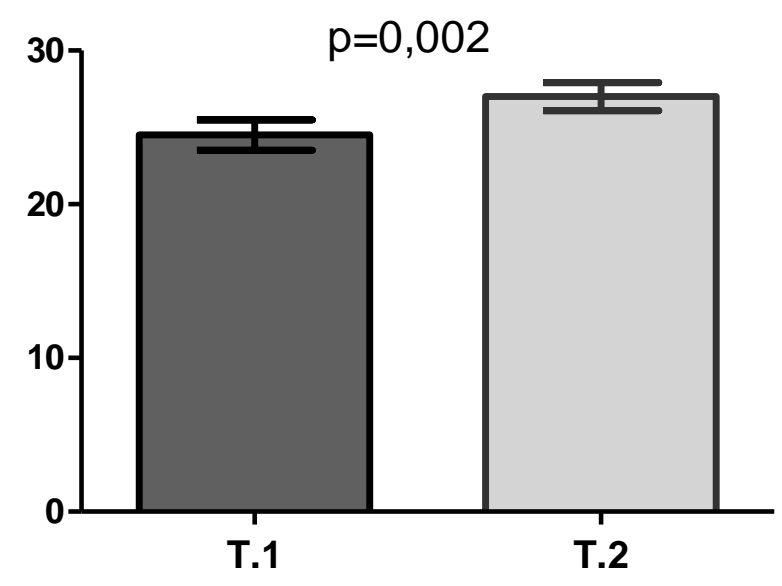

Figure 3. Trend for Task no. 2 - Push-ups Legend: T.1: Initial testing; T.2: Final testing.

Push-up test results show that one subject improved by 6 repetitions, one by 4 repetitions, four by 3 repetitions, two by 2 , and finally, two did not progress at all.

At the outset of the experiment the variability value was $14 \%$, and at the end it was $12 \%$, a $2 \%$ increase. Statistically, the group has medium variability, since the final calculated value fits in the $10-20 \%$ range. The difference between the two tests is statistically significant because the $\mathrm{P}$ value is 0.002 .

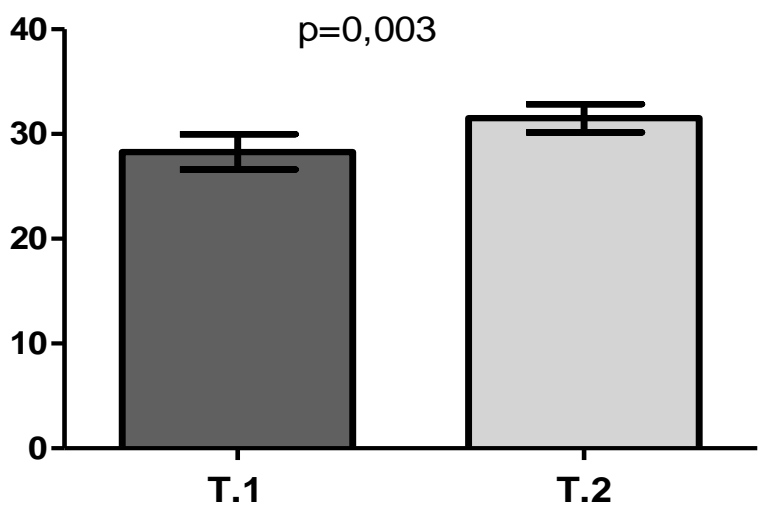

Figure 4. Trend for Task no. 4 - Squats Legend: T.1: Initial testing; T.2: Final testing.

Measured values for the initial squats test ranged between 15 and 35 repetitions, with a variability of $21 \%$. The final test registered values between 21 and 37 repetitions, with a variability of $14 \%$. 
Subject no. 10 achieved the greatest performance increase, bettering his score by 6 repetitions, one other subject outdoing his initial score by 5 repetitions, two subjects by 4 repetitions, two by 3 repetitions, 3 by 2 repetitions and one did not manage to improve.

The group exhibited medium variability for the squats test, since the final calculated value of $14 \%$ fits into the $10-20 \%$ range.

After calculating the value of $P(0.003)$ we can state that the difference between the two tests is significant.

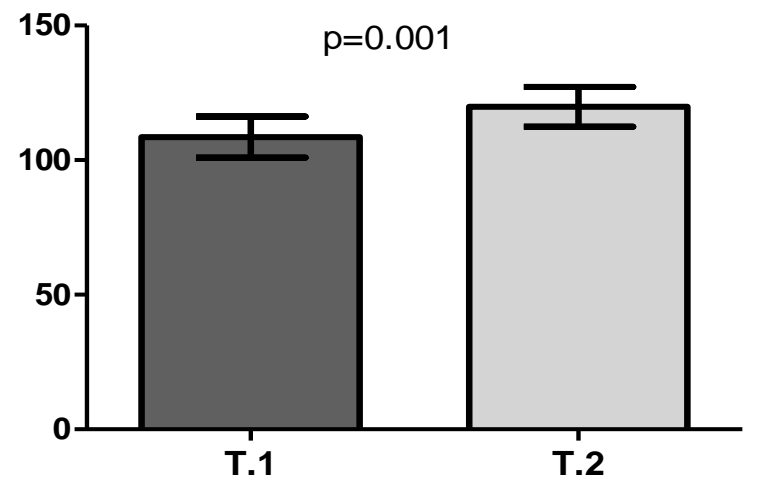

Figure 5. Trend for Task no. 4 - Standing broad jumps

Legend: T.1: Initial testing; T.2: Final testing.

Result analysis shows that while the initial test recorded values ranging between 53 and $140 \mathrm{~cm}$, the final test had results between 60 and $150 \mathrm{~cm}$. Subject no. 2 had the best performance increase, going from $95 \mathrm{~cm}$ at the start to 115 at the end.

Calculated initial variability had a value of $24 \%$, going down to $18 \%$ by the end of the experiment. The group has medium variability, since its final value can fit into the $10-20 \%$ range.

The value of $\mathrm{P}(0.001)$ indicates that the difference between the initial and final tests is statistically significant.

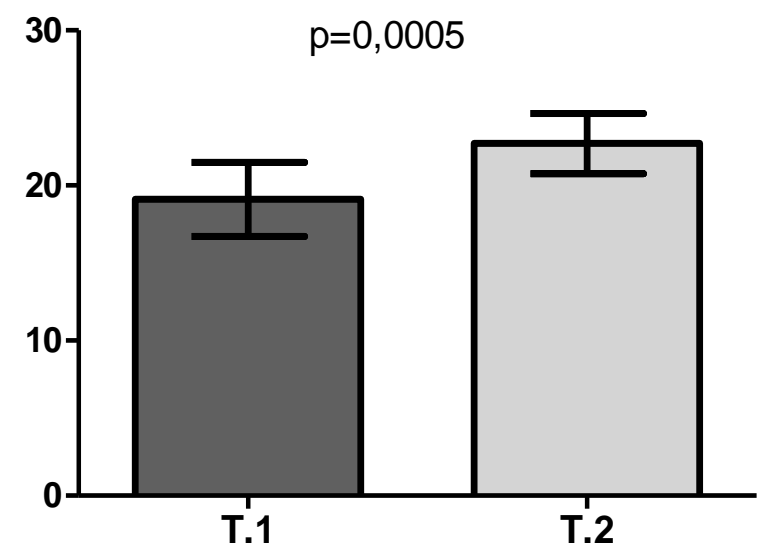

Figure 6. Trend for Task no. 5 - Abdominal crunches

Legend: T.1: Initial testing; T.2: Final testing.

Values for the initial test ranged between 7 and 29 repetitions, with a variability of $42 \%$, while values for the final test ranged between 15 and 30 repetitions, with a variability of $30 \%$.

Statistically the group is not homogeneous at all, since the variability value is $30 \%$, well over the $20 \%$ ceiling.

The difference between initial and final test results is statistically significant, since P equals 0.0005 .

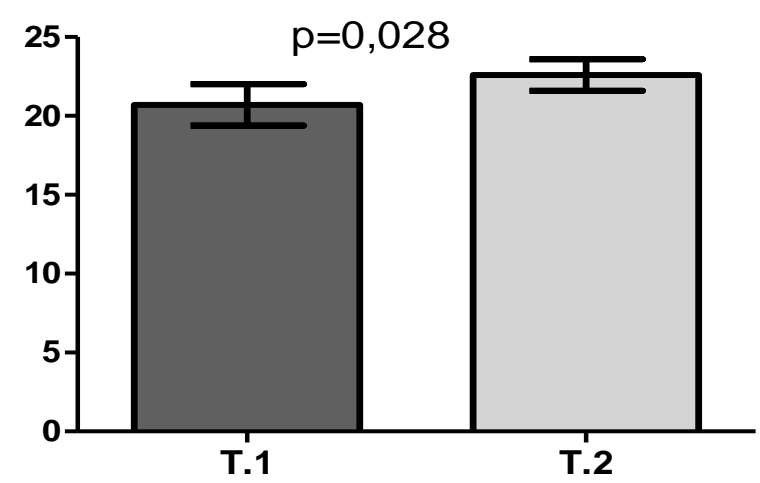

Figure 7. Trend for Task no. 6 - Back extensions Legend: T.1: Initial testing; T.2: Final testing.

The initial variability for this test was $20 \%$, measured values ranging between 14 and 20, while the final variability was $18 \%$, values ranging between 17 and 27.

Subjects no. two and 5 improved the most on their initial scores, by 5 extra repetitions. Six of the 
remaining subjects improved by 2 repetitions and two subjects improved by 1 repetition.

This test's results have medium variability, since the final calculated value fits in the $10-20 \%$ range.

The $P$ value $(0.028)$ indicates that the difference between the initial and final tests is statistically significant.

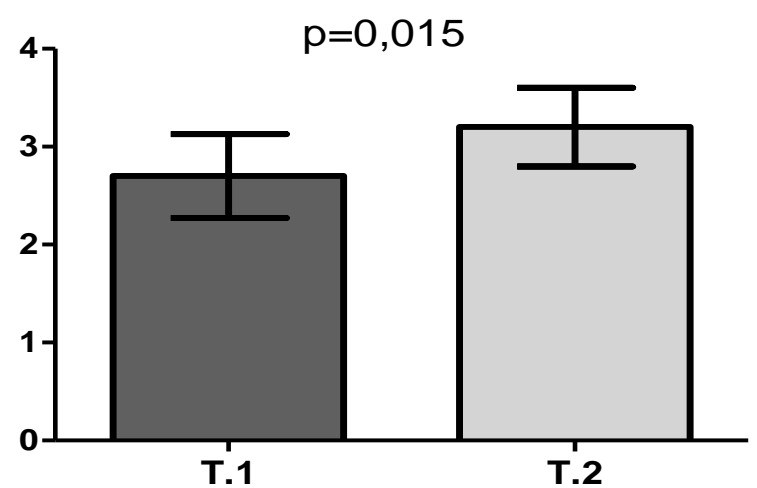

Figure 8. Trend for task no. 7 - Sit and reach test Legend: T.1: Initial testing; T.2: Final testing.

Values measured in the initial flexibility test ranged between 0 to $5 \mathrm{~cm}$, with a variability of $50 \%$. Subsequent performance in the final test ranged between 1 and $5 \mathrm{~cm}$, with variability dropping down to $47 \%$.

The difference between the two tests is statistically significant, since the calculated P value is 0.015 .

\section{Conclusions}

The final results show that the results of individual subjects improved, while group homogeneity increased, with statistically significant results.

While on the initial test, most tasks results lacked homogeneity, following the swimming lessons we observed medium variability of results, fitting into the $10-20 \%$ range. One task had results with lower variability, in the range of $0-10 \%$, while two tasks had higher variability, over $20 \%$.

The task that presented the best outcome was the one involving abdominal crunches, which improved on its variability by $12 \%$, while the tasks with the least progress were the ones involving push-ups and back extensions, at $2 \%$ improvement.

The results we obtained confirm the current paper's hypothesis, which states that basic swimming lessons have an important impact on the body, noticeably improving motor functions, as well as group homogeneity by the experiment's end.

\section{References}

1. Baniaș P. (2006). Curs Înot, Editura Universității de Vest Timişoara.

2. Cardon G., Verstraete S., Clercq D., Bourdeaudhuij I. (2004). Physical activity levels in elementary-school physical education: a comparison of swimming and non swimming classes. Journal of Teaching in Physical Education. (23) 3: 252-263.

3. Chase N.L., Sui X., Blair S.N. (2008). Comparison of the health aspects of swimming with other types of physical activity and sedentary lifestyle habits. International Journal of Aquatic Research and Education, 2, 151-161.

4. Ciosici D. (2003). Metodologia Cercetării Ştiinţifice, Edit. Mirton, Timișoara.

5. Eider P. (2015). Changes in motor skills of children who train sports swimming at the initial stage of school education (in annual training cycle). Pedagogics, psychology, medical-biological problems of physical training and sports; 12:109-119.

6. Eider P. (2014). Selection in swimming traing - Theoretical Study. Central European Journal of Sport Sciences and Medicine | Vol. 5, No. 1: 65-75.

7. Faur M. (2014). Teoria educției fizice și sportului, Edit. Mirton, Timișoara.

8. Grabowski H., Szopa J., EUROFIT. (1991). Physical Fitness Test Battery. Kraków: AWF;

9. Bielec G., Peczak-Graczyk A., Waade B. (2013). Do Swimming exercises induce anthropometric changes in adolescents? Issues in Comprehensive Pediatric Nursing, 2013; 36(1-2): 37-47

10. Olaru M. (1982). Înot, Editura Sport-Turism, Bucureşti.

11. Plăstoi C.D. (2008). Nataţie, Editura Academica Brâncuşi, Târgu-Jiu. 